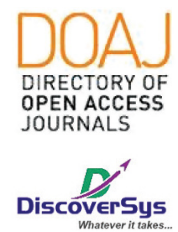

Published by DiscoverSys

\section{Hubungan petanda inflamasi dan hemoglobin pada obesitas di Fakultas Kedokteran Universitas Diponegoro periode Mei-September 2018}

\author{
Emelia Wijayanti ${ }^{1 *}$, Dwi Retnoningrum², Meita Hendrianintyas ${ }^{2}$
}

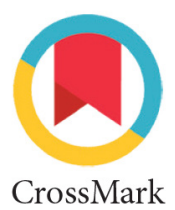

CrossMark

\begin{abstract}
Introduction: Obesity is one of global epidemic health problems. Obesity has been suggested to be associated with a state of chronic low-grade inflammation, which is characterized by abnormal cytokine production, increased acutephase reactants and activation of inflammatory signaling pathways. NLR (neutrofil to lymphocyte ratio) a simple and reliable indicator of inflammation, have been reported to be associatied with metabolyc syndrom, insulin resitence, and obeity in more study. Ferritin is a marker of inflammation contribute in obesity, and have been reported that ferritin is a marker of inflammation rather than iron status in overweight and obese people. Relationship between anemia and obesity may be due to fat a ccumulation and chronic inflammation in adipose tissue can be decreased iron absorbtion.
\end{abstract} (n)

Methods: Cross-sectional study of 50 obesity subject, based

on Riskesdas criteria, on Mei - September 2018. Marker of inflammation is ferritin serum was measured by ELISA (enzyme linked immunosorbent assay), and NLR and haemoglobin was perfomed from haematology analyzer. Spearman test was perfomed for analyzing data with $\mathrm{p}<0,05$ was significant

Results: No correlation between NLR and haemoglobin, $r=0,067$ and $p=0,642$, and significant strong positive correlation between ferritin and haemoglobin, $r=0,630$ and $p<0,000$.

Conclusion: There was no correlation between NLR and haemoglobin, and there was significant strong positive correlation between ferritin and haemoglobin in obesity. Future research need to observe with evaluate hepcidin, other iron status parameter and marker of inflammation.

Keywords: Obesity, NLR, ferritin, haemoglobin

Cite This Article: Wijayanti, E., Retnoningrum, D., Hendrianintyas, M. 2019. Hubungan petanda inflamasi dan hemoglobin pada obesitas di Fakultas Kedokteran Universitas Diponegoro periode Mei-September 2018. Intisari Sains Medis 10 (1): 242-246. D0I: 10.1556/ism. v10i1.347

'Residen Patologi Klinik, Fakultas Kedokteran Universitas Diponegoro, Semarang, Indonesia ${ }^{2}$ Staf Bagian Patologi Klinik, Fakultas Kedokteran Universitas Diponegoro, Semarang, Indonesia

* Korespondensi:

Emelia Wijayanti; Residen Patologi Klinik, Fakultas Kedokteran Universitas Diponegoro, Semarang, Indonesia; pinkzz90@yahoo.com

Diterima : 09-11-2018

Disetujui : 11-03-2019

Diterbitkan : 01-04-2019

\section{ABSTRAK}

Pendahuluan: Obesitas merupakan salah satu masalah kesehatan global. Obesitas dikaitkan dengan keadaan inflamasi kronis tingkat rendah yang ditandai oleh produksi sitokin abnormal, peningkatan protein fase akut dan aktivasi jalur sinyal inflamasi. NLR (neutrofil to lymphocyte ratio) sebagai petanda inflamasi yang mudah dan murah, terbukti berhubungan dengan sindrom metabolik, resisten insulin dan obesitas pada beberapa penelitian. Ferritin suatu petanda inflamasi dikaitkan dengan obesitas dan dikatakan bahwa ferritin merupakan petanda inflamasi daripada petanda status besi pada obesitas atau kelebihan berat badan. Obesitas berkaitan dengan anemia karena penimbunan lemak dan inflamasi kronis di jaringan adiposa dapat menurunkan penyerapan zat besi.

Metode: Penelitian belah lintang pada 50 orang obesitas berdasarkan kriteria Riskesdas pada bulan Mei - September
2018. Petanda inflamasi adalah ferritin serum diperiksa dengan metode ELISA (enzyme linked immunosorbent assay) dan NLR dan hemoglobin diperiksa menggunakan haematology analyzer. Uji Korelasi spearman digunakan untuk menganalisis data, signifikan jika $p<0,05$.

Hasil: Tidak terdapat korelasi antara NLR dengan Hemoglobin, $r=0,067$ dan $p=0,642$, dan terdapat korelasi positif kuat antara ferritin dengan hemoglobin, $r=0,630$ dan $p<0,000$.

Simpulan: Tidak terdapat hubungan antara NLR dengan hemoglobin, dan terdapat hubungan positif kuat antara ferritin dan hemoglobin pada obesitas. Perlu dilakukan penelitian lanjutan dengan menilai hepsidin, parameter status besi dan petanda inflamasi lain. 


\section{PENDAHULUAN}

Obesitas merupakan masalah kesehatan dan ekonomi utama yang signifikan secara global. Angka prevalensi meningkat di semua bagian dunia, baik di negara-negara Barat yang makmur maupun di negara-negara miskin. ${ }^{1}$ Obesitas telah mencapai proporsi epidemi secara global, lebih dari 1 miliar orang dewasa memiliki kelebihan berat badan dan 300 juta di antaranya mengalami obesitas secara klinis yang merupakan penyumbang utama terhadap beban global penyakit kronis dan disabilitas. ${ }^{2}$ Prevalensi obesitas dunia pada orang dewasa mengalami peningkatan sebesar 8,7 $13,1 \%$, yaitu sebesar $10,5-15,1 \%$ pada wanita dan $6,6-11,1 \%$ pada laki - laki. Prevalensi di negara Asia yang menjadi anggota WHO juga mengalami peningkatan dari tahun 2000 - 2016 sebesar 1,9$4,7 \% ; 2,7-6,1 \%$ pada wanita dan $1,1-3,3 \%$ pada laki - laki. ${ }^{3}$ Prevalensi obesitas di Indonesia pada tahun 2016 sebesar $20,7 \%$ meningkat dari $15,4 \%$ pada tahun 2013. Prevalensi obesitas secara nasional pada perempuan lebih tinggi $(41,6 \%)$ dibandingkan pada laki-laki $(24,0 \%){ }^{4,5}$

Obesitas didefinisikan sebagai kelebihan kandungan lemak di jaringan adiposa. Batas untuk obesitas umumnya adalah kelebihan berat lebih daripada 20\% standar normal. Penentuan obesitas pada orang dewasa menggunakan boddy mass index (BMI) atau indeks massa tubuh (IMT). ${ }^{1,6,7}$ Seseorang dikatakan obesitas apabila IMT $>27.4,5$ Kriteria WHO menyatakan obesitas apabila IMT

Tabel 1. Karakteristik Data Subjek Penelitian

\begin{tabular}{lccc}
\hline \multicolumn{1}{c}{ Variabel } & Frekuensi & Mean \pm SD & Median (min - mak) \\
\hline Jenis kelamin & & & \\
$\quad$ Laki-laki & 24 & & \\
$\quad$ Perempuan & 26 & & $20(18-46)$ \\
Umur (tahun) & & $24,14 \pm 7,59$ & $31,6(27,3-49)$ \\
BMI $\left(\mathrm{kg} / \mathrm{m}^{2}\right)$ & & $33,11 \pm 4,72$ & $1,92(1,12-4,35)$ \\
NLR & & & \\
Feritin $(\mathrm{ng} / \mathrm{ml})$ & & \\
Laki - laki & & & \\
$\quad$ Rendah $(<30 \mathrm{ng} / \mathrm{ml})$ & 3 & & \\
$\quad$ Normal $(30-350 \mathrm{ng} / \mathrm{ml})$ & 21 & & \\
Perempuan & & & \\
$\quad$ Rendah $(<20 \mathrm{ng} / \mathrm{ml})$ & 11 & & \\
$\quad$ Normal $(20-250 \mathrm{ng} / \mathrm{ml})$ & 15 & & \\
Hb $(\mathrm{gr} / \mathrm{dL})$ & & & \\
Laki - laki & & & \\
$\quad \geq 13 \mathrm{gr} / \mathrm{dL}$ & & & \\
$\quad<13 \mathrm{gr} / \mathrm{dL}$ & 23 & & \\
Perempuan & & & \\
$\quad \geq 12 \mathrm{gr} / \mathrm{dL}$ & & & \\
$\quad<12 \mathrm{gr} / \mathrm{dL}$ & 5 & & \\
\hline
\end{tabular}

Catatan: SD (standar deviasi); min (minimal); mak (maksimal)
$>30 .{ }^{8}$ Penyebab obesitas bermacam-macam antara lain kelainan neuroendokrin, pola makan, gaya hidup, faktor sosial ekonomi, genetik dan lain sebagainya. ${ }^{9}$

Obesitas dikaitkan dengan keadaan inflamasi kronis tingkat rendah. Kondisi ini ditandai oleh produksi sitokin abnormal, peningkatan protein fase akut dan aktivasi jalur sinyal inflamasi. ${ }^{10-13}$ Beberapa penelitian menunjukkan adanya peningkatan petanda inflamasi pada pasien obesitas. ${ }^{13-15}$

Beberapa penelitian menunjukkan peningkatan neutrofil, limfosit dan hitung leukosit total terkait dengan gangguan metabolisme yang diinduksi obesitas. ${ }^{16-21}$ Rasio neutrofil limfosit atau neutrophil to lymphocyte ratio (NLR) adalah perbandingan neutrofil dan limfosit yang terbukti sebagai petanda inflamasi, berhubungan dengan sindrom metabolik, resisten insulin dan obesitas pada beberapa penelitian..$^{22-25}$

Ferritin suatu petanda inflamasi yang dikaitkan dengan obesitas pada beberapa penelitian dan dikatakan bahwa ferritin merupakan petanda inflamasi daripada petanda status besi pada obesitas atau kelebihan berat badan. ${ }^{26-28}$ Ferritin berada dalam kesetimbangan dengan simpanan tubuh, dan konsentrasinya menurun pada awal perkembangan defisiensi zat besi. Konsentrasi ferritin serum yang rendah merupakan indikator sensitif defisiensi zat besi. $^{29}$

Obesitas berkaitan dengan anemia karena penimbunan lemak dan inflamasi kronis di jaringan adiposa dapat menurunkan penyerapan zat besi. ${ }^{30,31}$ El-kerdany dkk Menyebutkan bahwa Kadar hemoglobin menurun seiring dengan meningkatnya BMI..$^{31-33}$

Berdasarkan uraian adanya peningkatan ferritin dan juga NLR sebagai petanda inflamasi pada obesitas serta adanya perubahan hemoglobin pada obesitas, maka studi ini bertujuan untuk mengetahui lebih lanjut apakah terdapat hubungan antara petanda inflamasi dengan kadar hemoglobin pada populasi obesitas di Fakultas Kedokteran Universitas Diponegoro periode Mei-September 2018

\section{METODE PENELITIAN}

Penelitian ini menggunakan desain potong lintang (cross-sectional) yang dilakukan selama bulan Mei - September 2018 di lingkungan FK UNDIP Semarang. Protokol penelitian ini sudah disetujui oleh Komite Etik Penelitian Kedokteran dan Kesehatan FK UNDIP Semarang, No. 285/ EC/FK-RSDK/V/2018. Penelitian ini menginklusi subjek laki - laki dan perempuan berusia produktif dengan IMT $>27 \mathrm{~kg} / \mathrm{m}^{2}$, sedangkan kriteria eksklusi 


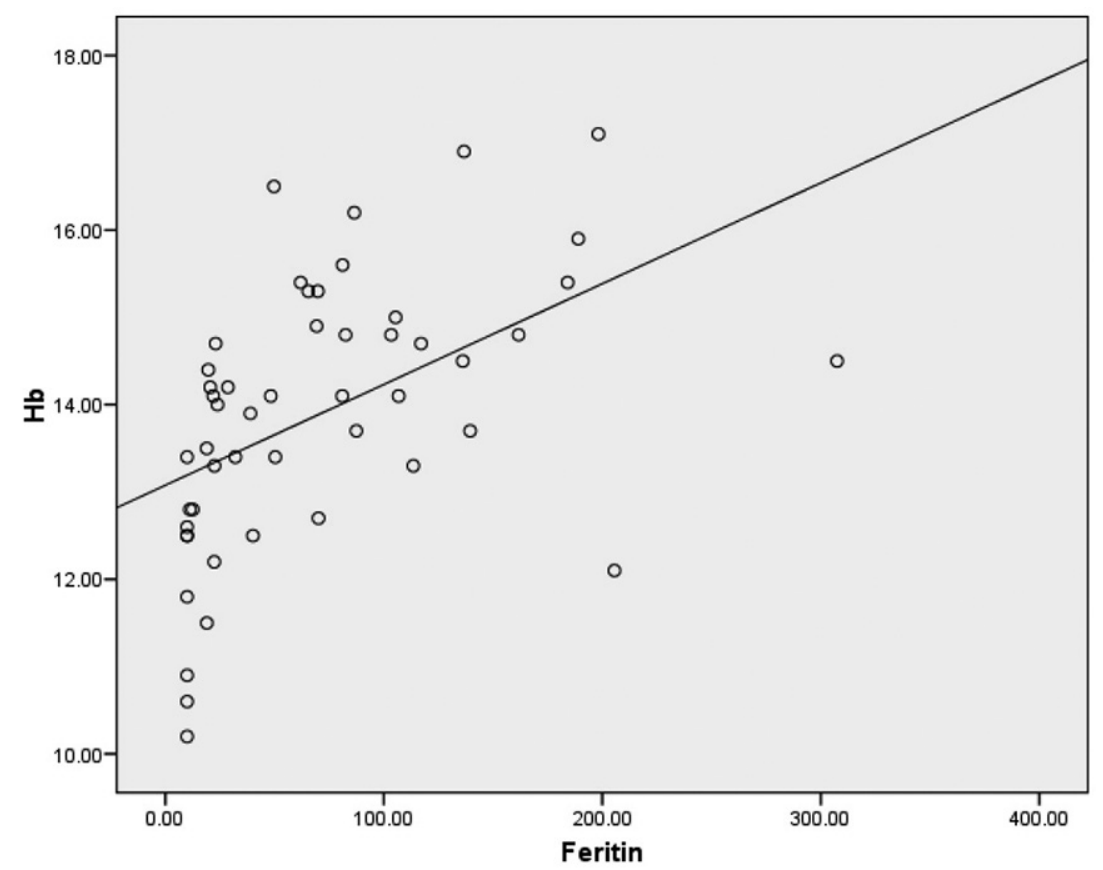

Gambar 1. Korelasi antara Ferritin dengan Hemoglobin

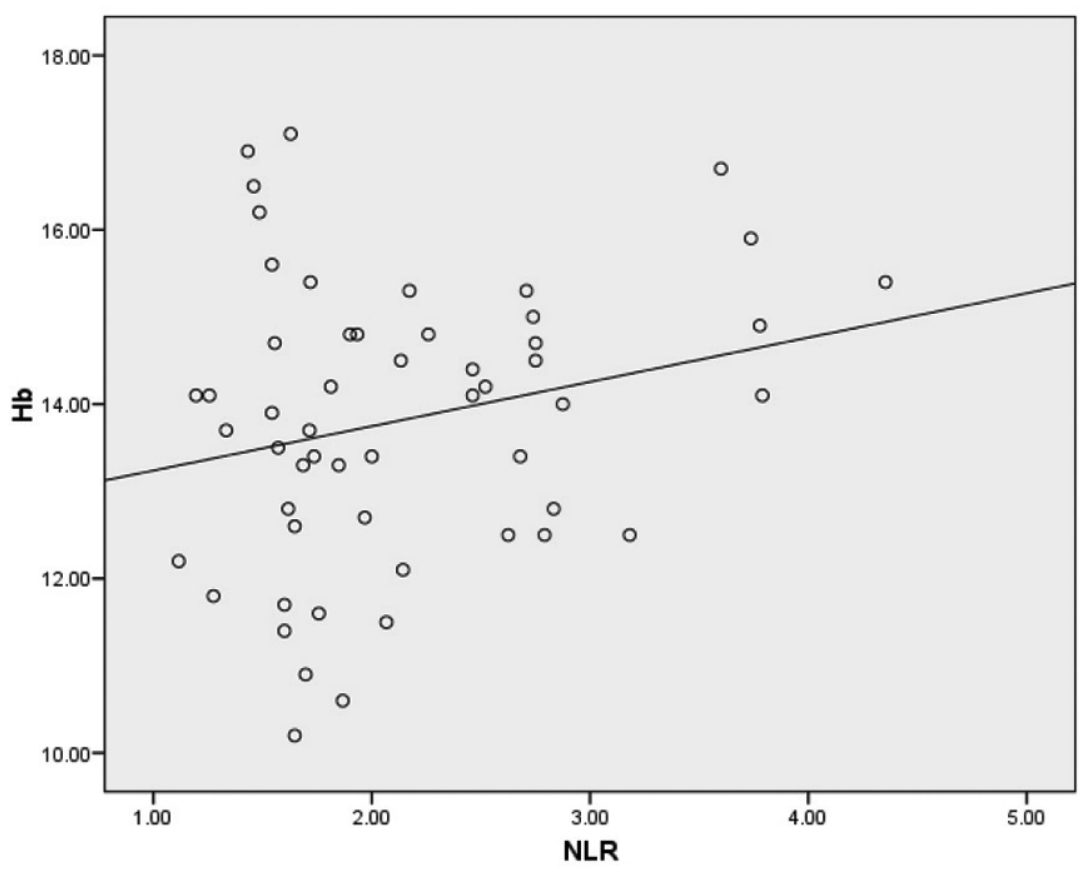

Gambar 2. Korelasi antara NLR dengan Hemoglobin

adalah wanita hamil, anemia, dan riwayat penyakit sistemik. Petanda inflamasi yang diperiksa adalah ferritin serum dengan metode ELISA (enzyme linked immunosorbent assay) dan NLR yang didapatkan dari perhitungan ANC (absolute neutrofil count) dibagi dengan ALC (absolute lymphocyte count). Hemoglobin diperiksa menggunakan haematology analyzer. Sampel dipilih mengunakan teknik konsekutif (consecutive sampling).

Analisis statistik pada penelitian ini menggunakan SPPS versi 15.0. Data ditampilkan sebagai mean \pm standar deviasi atau median dengan nilai minimum dan maksimum. Hubungan antara ferritin dan NLR dengan hemoglobin diuji menggunakan uji korelasi Spearman. Kebermaknaan ditegakkan berdasarkan nilai $\mathrm{p}$ $<0,05$.

\section{HASIL}

Sebanyak 50 subjek ikut serta dalam penelitian ini terdiri dari 24 laki - laki (48\%) dan 26 perempuan (52\%). Rerata umur 24 tahun dan rerata BMI 33 dengan standar deviasi 4,72. Karakteristik data dapat dilihat pada Tabel 1.

Nilai NLR didapatkan median 1,92 dengan nilai minimum 1,12 dan maksiumum 4,35. Nilai ferritin pada penelitian ini didapatkan median 50,03 dengan nilai minimum 9,99 dan maksimum 307,45 . Nilai hemoglobin didapatkan rerata 13,9 dengan standar deviasi 14,1.

Tidak terdapat korelasi antara NLR dengan hemoglobin, $r=0,067$ dan $\mathrm{p}=0,642$ (Gambar 1), dan terdapat korelasi positif kuat antara ferritin dengan hemoglobin, $r=0,630$ dan $\mathrm{p}<0,000$ (Gambar 2). Hal ini menunjukkan bahwa semakin tinggi kadar ferritin serum maka berkorelasi dengan semakin tingginya kadar hemoglobin saat pemeriksaan.

\section{PEMBAHASAN}

Obesitas dikaitkan dengan keadaan inflamasi kronis tingkat rendah. Kondisi ini ditandai oleh produksi sitokin abnormal, peningkatan protein fase akut dan aktivasi jalur sinyal inflamasi. ${ }^{10-13}$ Beberapa penelitian menunjukkan adanya peningkatan petanda inflamasi pada pasien obesitas. ${ }^{13-15}$

NLR merupakan parameter petanda inflamasi yang dihitung dari rasio antara ANL dan ALC yang mudah dan murah, pada penelitian ini NLR tidak memiliki hubungan dengan kadar hemoglobin. Hal ini sejalan dengan penelitian yang dilakukan oleh Gorphe dkk, dimana hemoglobin dan NLR tidak berkorelasi, sama hal-nya dengan hitung neutrofil dan hitung limfosit. ${ }^{34}$ Bahadir dkk melaporkan bahwa NLR tidak berkorelasi dengan IMT, dan bukan merupakan indikator yang baik untuk inflamasi, dimana leukosit dan Hs-CRP (high sensitive $C$ - reactive protein) lebih berguna untuk mengindikasikan inflamasi pada pasien obesitas dan sindrom metabolik. ${ }^{35}$ Obesitas secara progesif bertanggung jawab untuk pengembangan diabetes melitus dan aterosklerotik berhubungan dengan disfungsi endotel. Disfungsi endotel berkembang di bawah sitokin pro-inflamasi seperti IL-6 
(interleukin 6), dan TNF-a (tumor necrosing factor - alpha).

Ferritin cenderung lebih tinggi pada orang dengan berat badan berlebih dan obesitas, dikarenakan keadaan subklinis dan inflamasi. ${ }^{36}$ Penelitian oleh Koperdanova 2015 dan Khan dkk. 2016 menyatakan bahwa ferritin merupakan petanda inflamasi daripada petanda status besi pada pasien dengan obesitas. ${ }^{37}$ Penelitian ini kontras dengan penelitian sebelumnya dimana ferritin berkorelasi positif dengan hemoglobin. Anari dkk melaporkan tidak ada perbedaan dalam kadar hemoglobin, MCV (mean corpuscular volume), status besi, indek saturasi transferin, dan ferritin antara berat badan normal, berat badan berlebih, dan obesitas. Hal ini mungkin dikarenakan nutrisi yang baik pada orang obesitas, seperti konsumsi makanan tinggi besi. ${ }^{38}$

Obesitas menyebabkan peradangan kronis yang berhubungan dengan ekspresi dan pelepasan sitokin proinflamasi termasuk interleukin-6 (IL6) dan tumor necrosis factor-alpha (TNF- $\alpha$ ). ${ }^{39}$ Hepsidin ditemukan meningkat pada penyakit inflamasi medan mengarah pada anemia penyakit kronik. Hepsidin memainkan peran dalam homeostasis besi, terdapat korelasi antara hepsidin dengan beberapa sitokin seperti IL-6 dan CRP yang juga meningkat pada obesitas. Defisiensi besi pada obesitas merupakan hasil dari gangguan metabolisme besi yang berhubungan dengan hepsidin yang menurunkan penyerapan besi dan meningkatkan iron sequestration. ${ }^{40}$ Penelitian ini tidak memeriksa parameter sitokin proinflamasi dan hepsidin serta parameter status besi lain sehingga tidak bisa dilihat pengaruh penyerapan besi.

\section{SIMPULAN DAN SARAN}

Terdapat hubungan positif kuat antara ferritin dan hemoglobin dan tidak terdapat hubungan antara NLR dan hemoglobin pada obesitas. Perlu dilakukan penelitian lanjutan dengan menilai parameter status besi lain seperti serum besi, TIBC, indek saturasi transferin, dan hepsidin, serta petanda inflamasi lain seperti CRP, IL-6, TNF- $\alpha$.

\section{DAFTAR PUSTAKA}

1. Bjorntorp P. International textbook of obesity $1 \mathrm{t}$ ed. Huangzhiman: Wiley; 2002.12.19.3p

2. World Health Organization. Obesity and overweight. USA: World Health Organization; 2016.

3. World Health Organization. Global health observatory data repisitory prevalence obesity among adults. 2012. Available from URL: http://apps.who.int/gho/data/view. main.REGION2480A?lang=en. [Diakses pada 17 Agustus 2018].

4. Badan Penelitian dan Pengembangan Kesehatan
Kementerian Kesehatan RI. Laporan Survei Indikator Kesehatan Nasional (Sirkesnas). 2016.

5. Badan Penelitian dan Pengembangan Kesehatan Kementerian Kesehatan RI. 2013.

6. Sherwood L. Fisiologi manusia: dari sel ke sistem. Edisi 8, diterjemahkan oleh Brahm U. Pendit. Jakarta: EGC; 2014: $682-4$

7. Sudoyo AW, Setyohadi B, Alwi I, et al. Obesitas, buku ajar ilmu penyakit dalam Jilid III Edisi V. Jakarta: Interna Publishing Pusat Penerbitan Ilmu Penyakit Dalam. 2009: 1921-2.

8. WHO expert consultation. Appropriate body-mass index for Asian populations and its implications for policy and intervention strategies. Lancet. 2004:157-63.

9. Bray AG, Bouchard C. Hadbook of obesity clinical application 2nd ed. New York: Marcel Dekker, Inc; 2004: 3-8.

10. Spyridaki EC, Avgoustinaki PD, Margioris AN. Obesity, inflammation and cognition. Behavioral Sciences. 2016; 9:169-75.

11. Castro AM, Concha LE, Meléndez CA. Low-grade inflammation and its relation to obesity and chronic degenerative diseases. Rev Med Hosp Gen Méx. 2017; $80(2): 101-5$.

12. Warnberg J, Morena LA, Mesana MI, et al. Inflammatory mediators in overweight and obese in Spanish adolescents. The AVENA Study. International Journal of Obesity. 2004; 28:S59-S63.

13. Rodríguez-Hernández H, Simental-Mendía LE, RodríguezRamírez G, Reyes-Romero MA. Obesity and inflammation: epidemiology, risk factors, and markers of inflammation. Int J Endocrinol. 2013; 2013:678159

14. Monteiro R, Azevedo I. Chronic inflammation in obesity and themetabolic syndrome. Mediators Inflamm. 2010; 2010. pii: 289645

15. Ellulu MS, Patimah I, Khazảai H, Rahmat A, Abed Y. Obesity and inflammation: the linking mechanism and the complications. Arch Med Sci. 2017; 13(4):852-63.

16. $\mathrm{Xu} \mathrm{X,} \mathrm{Su} \mathrm{S,} \mathrm{Wang} \mathrm{X,} \mathrm{et} \mathrm{al.} \mathrm{Obesity} \mathrm{is} \mathrm{associated} \mathrm{with} \mathrm{more}$ activated neutrophils in African-American male youth. Int J Obes (Lond). 2015; 39(1):26-32.

17. Dixon JB, O' Brien PE. Obesity and the white blood cell count: changes with sustained weight loss. Obes Surg. 2006; 16(3):251-7.

18. Furuncuoğlu Y, Tulgar S, Dogan AN, Cakar S, Tulgar YK, Cakiroglu B.. How obesity affects the neutrophil/ lymphocyte and platelet/lymphocyte ratio, systemic immune-inflammatory index and platelet indices: a retrospective study. Eur Rev Med Pharmacol Sci. 2016; 20(7):1300-6.

19. Cinkajzlová A, Mráz M, Haluzík M. Lymphocytes and macrophages in adipose tissue in obesity: markers or makers of subclinical inflammation? Protoplasma. 2017; 254(3):1219-32.

20. Kim JA, Park HS. White blood cell count and abdominal fat distribution in female obese adolescents. Metabolism. 2008; 57(10):1375-79.

21. Jamshidi L, Seif A. Association between obesity, white blood cell and platelet count. Zahedan J Res Med Sci. 2017; 19(2):e4955

22. Buyukkaya E, Karakas MF, Karakas E, et al. Correlation of neutrophil to lymphocyteratio with the presence and severity of metabolic syndrome. Clinical and Applied Thrombosis/Hemostasis. 2014; 20(2):159-63.

23. Khandare SA, Chittawar S, Nahar N, Dubey TN, Qureshi Z. Study of neutrophil-lymphocyte ratio as novel marker for diabetic nephropathy in type 2 diabetes. Indian J Endocrinol Metab. 2017; 21(3):387-392

24. Lou M, Luo P, Tang R, Peng Y, Yu S, Huang W, He L. 
Relationship between neutrophil-lymphocyte ratio and insulin resistance in newly diagnosed type 2 diabetes mellitus patient. BMC Endocr Disord. 2015;15(9):6p.

25. Serbanescu C, Topor L, Fronea IG, Nilla A, Sirbu A, Fica S. Neutrophil to lymphocyte ratio: relationship with anthropometric and metabolic parameters in morbidly obese patients. Endrocine abstract. 2015;37:EP615

26. Khan A, Khan WM, Ayub M, Humayun M, Haroon M. Ferritin is a marker of inflammation rather than iron deficiency in overweight and obese people. J Obes. 2016;2016:1937320

27. Gartner A, Berger J, Bour A, El Ati J, Traissac P, Landais E, El Kabbaj S, Delpeuch F.. Assessment of iron deficiency in the context of the obesity epidemic: importance of correcting serum ferritin concentrations for inflammation. Am J Clin Nutr. 2013; 98(3):821-6.

28. Park SK, Choi WJ, Oh CM, Kim J, Shin H, Ryoo JH. Association between serum ferritin levels and the incidence of obesity in Korean men: A prospective cohort study. Endocr J. 2014; 61(3):215-24.

29. World Health Organization (WHO). Iron deficiency anaemia - Assessment, prevention, and control. A guide for programme managers. Geneva: World Health Organization; 2001 (WHO/NHD/01.3). Available from: http://www.who.int/nutrition/publications/en/ida assessment_prevention control.pdf. [Diakses pada 17 Agustus 2018]

30. Cepeda-Lopez AC, Osendarp SJ, Melse-Boonstra AM, Aeberli I, Gonzalez-Salazar F, Feskens E, Villalpando $S$, Zimmermann MB. Sharply higher rates of iron deficiency in obese Mexicanwomen and children are predicted by obesity-related inflammation rather than by differences in dietary iron intake. Am J Clin Nutr. 2011; 93(5):975-83.

31. El-kerdany TA, Fahmy WA, Eissa DG, Hassan M. Relationship between obesity and iron deficiency. The Egyptian Journal of Hospital Medicine. October 2017; 69(4):2204-8.

32. Altunoğlu E, Müderrisoğlu C, Erdenen F, et al. The impact of obesity and insulin resistance on iron and red blood cell parameters: a single center, cross-sectional study. Turk J Hematologi. 2014;31:61-7.
33. Bagni UV, Luiz RR, Veiga GV. Overweight is associated with low hemoglbin in adoloescent girl. Obes Res Clin Pract. 2013; 7(3):e218-29.

34. Gorphe P, Idrissi YC, Tao Y, Schernberg A, Ou D, Temam S, Casiraghi O, Blanchard P, Mirghani H. Anemia and neutrophil to lympocyte ratio are prognostic in p16positive oropharygeal carcinoma treated with concurent chemoradiation. Papillomavirus Res. 2018; 5:32-7.

35. Bahadir A, Baltaci D, Turker Y, Türker Y, Iliev D, Öztürk S, Deler MH, Sarıüzel YC.. Is the neutrophil-tolymphocyte ratio indicative of inflammatory state in patients with obesity and metabolic?. Anatol J Cardiol. 2015; 15(10):816-22.

36. Jeon YJ, Jung IA, Kim SH, Cho WK, Jeong SH, Cho KS, Park SH, Jung MH, Suh BK. Serum ferritin level is higher in male adolescents with obesity: results from the Korean National Health and Nutrition Examination Survey 2010. Ann Pediatr Endocrinol Metab. 2013; 18(3):141-7.

37. Royal College of Pathologists of Australasia. Interpreting serum ferritin. Lam Q, editor. Australia: Cirrus Media. 2013:8.

38. Ghadiri-Anari A, Nazemian N, Vahedian-Ardakani HA. Association of body mass index with hemoglobin concentration and iron parameters in Iranian population. ISRN Hematol. 2014; 2014: 525312.

39. Shekarriz R, Vaziri MM. Iron Profile and Inflammatory Status of Overweight and Obese Women in Sari, North of Iran. Int J Hematol Oncol Stem Cell Res. 2017; 11(2):108113.

40. Zhang AS. Control of systemic iron hoeostasis by the hemojuvelin-hepcidin axis. Adv Nutr. 2010; 1(1):38-45.

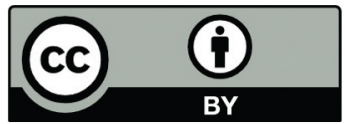

This work is licensed under a Creative Commons Attribution 